\title{
Public nuisance or an asset to democracy? Does the free press aim to provide a public service? An empirical study examining journalistic functions within the normative framework of the European Union
}

\author{
Marie-Isabell Lohmann, Austrian Academy of Sciences, Institute for Comparative Media and \\ Communication Studies \\ Andreas Riedl, Austrian Academy of Sciences, Institute for Comparative Media and Communication \\ Studies* \\ *corresponding author: andreas.riedl@oeaw.ac.at
}

\begin{abstract}
Utilizing an empirical approach, this paper lays out how journalistic functions differ from the perception of journalists working for the free and paid press in Austria. Analyses indicate that free press journalists appear to be significantly more inclined to generate discourse with their audience, but are also more influenced by commercialization than their colleagues working for the paid press. Both the free and paid press seem to fulfill diverging democratic functions that can be valuable to the public. Finally, the normative notion of journalistic functions as legislated by the European Union (EU) seems only partially represented within the journalists' self-perception.
\end{abstract}

Keywords

Free dailies, journalistic functions, Worlds of Journalism Study WJS, European Union

\section{Introduction}

While other European countries might be experiencing a decline in printed newspapers, Austria's daily press is still strong. However, its composition has been subject to a profound transition within the last two decades. While the most dominant tabloid newspaper, Kronen Zeitung (Magin \& Stark, 2015), has lost a significant amount of market share, free daily tabloids ${ }^{1}$ were quick to fill the void and dominate the market (Bakker, 2013), recently accounting for at least a third of the distributed circulation of all printed newspapers (ÖAK, 2016), and there are no signs of a decline in the close future so far.

1 This paper uses the terms "free tabloids," "free newspaper," "free press" and "free papers" etc. based on a common understanding (see also Ballarini, Alves, \& Lamour, 2017) to describe press products "that are given away free of charge to readers" (Serazio, 2009, p. 649), which must not be confused with "free press" referring to "freedom of the press" as a concept (Russomanno, 2008).
The phenomenon described, seen within the context of increased economization of the profession, casts an alarming light on the future of journalism altogether (Lee-Wright, Phillips, \& Witschge, 2011). While the rise of free dailies bears considerable consequences for the profession from an economic point of view by redefining market mechanisms and logistics on many levels, the transition might have serious implications with regards to the dailies' ability to fulfill democratic functions (Bakker \& Seethaler, 2009).

As one of the most crucial functions of mass media, the public service function expects Western journalism to generate public attention for politically relevant issues, enable democratic processes, monitor the government, and provide public value (ECHR, 1979; Moore, 1995; Palmstorfer, 2015). The expectation placed on journalists to fulfill this public function is not only inexorable, it has also been codified in European law, thereby even legitimizing certain violations of the right to 
privacy of European citizens (ECHR, 1985; Emerson, 1979).

Beyond their given constitutional protection, much is demanded of journalists in the 28 European Union (EU) Member States, and thus in Austria. With regard to the rise of free daily newspapers in several European countries and the recent developments and transitions in journalism, the following questions arise (Lee-Wright, Phillips, \&Witschge, 2011):

, Can the emerging model of free daily newspapers be of service to the public?

, How do journalists employed by free media perceive and/or aim to exercise their attributed democratic role compared to journalists working in paid media?

These questions will be explored using a classification of public functions - information, monitoring and communication by legal scholar Nina Palmstorfer (2015) and utilizing a representative sample of 818 Austrian journalists from the Worlds of Journalism Study (WJS). Their self-reported data contains compelling insights into the adoption of public service functions by journalists in paid and free print press. Furthermore, the results put the normative notion of journalistic functions as determined by the aforementioned EU legislation into question.

\section{Background}

Often called "the country of media monopolies," Austria is home to a media market that is traditionally associated with an atypically high media concentration in terms of market share as well as media ownership (Steinmaurer, 2008). Following a long period of relatively stable market conditions, the Austrian media system faced fundamental changes within the print and broadcasting sector throughout the last two decades. While the paid tabloid newspaper Kronen Zeitung dominated the print sector for decades, an emerging market share of free daily newspapers caused a long-lasting stir in the newspaper indus- try from the early 2000s onwards. Similar developments could be observed in other media sectors. The Austrian public service broadcaster, ORF, simply did not have to face any Austrian competitors since the foundation of the republic, but the introduction of the dual system of public and private broadcasters in 2001 (Trappel, 2007) transformed a highly regulated media segment into a more liberal one.

Contrary to the sustained rise of new communication technologies via the ubiquitous use of social network services as observed in many other countries, the success of free daily newspapers seems to be a very Austrian characteristic. In contrast to international trends, where the rise of free daily newspapers mostly remained a temporary phenomenon, Austrian free dailies came to stay (Bakker, 2015). They recently accounted for one third of the total circulation of all distributed newspapers in Austria (ÖAK, 2016), and their market share continues to increase. It might come as no surprise that the free dailies mainly feed on the market share of paid tabloid newspapers as they seem to fulfill similar demands. However, paid quality newspapers struggle significantly less to maintain their market position. As is evident in Figure 1, the slow but steady decrease in total circulation of paid daily newspapers is mostly caused by the constant loss of Austria's most read tabloid newspaper, Kronen Zeitung - most other paid newspapers show considerably stable demand. Even though Kronen Zeitung is continuously losing reach compared to the free dailies, it is still the strongest player in the market with a current (2015) reach of 32.0 percent (compared to 44.9 percent in 2005). It seems reasonable to assume that the historical dominance of this tabloid newspaper paved the way for the free dailies, which operate with a very similar format and style and were therefore quickly liked by the public.

Interestingly enough, the Austrian wave of free dailies was started by the very publisher of Kronen Zeitung, Hans Dichand. By launching the free daily $U$ Express, he aimed at filling this niche himself and compensating for the Kronen 
Figure 1: The development of the total circulation of daily newspapers in Austria 2005-2015

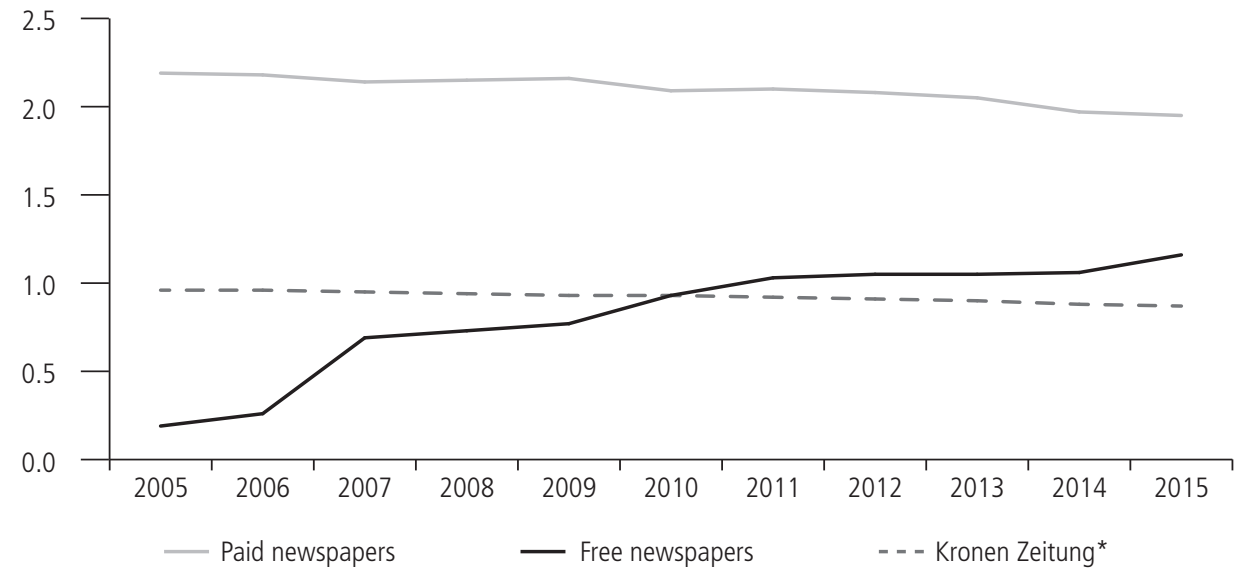

Note. Average weekly (Monday-Sunday) distributed circulation (purchase and free of charge; excluding foreign circulation) in millions; *Kronen Zeitung is also included in "Paid newspapers" (Source: Österreichische Auflagenkontrolle, own calculations).

Zeitung's crumbling market shares. However, his German partner shareholders forced him to reject this project in 2004 (derstandard.at, 2015) in order to protect the Kronen Zeitung from self-made competition. Based on a sophisticated ownership construction which could evade from the legal influence of the business partners, it was Dichand's daughter, Eva, who realized a similar plan only a short time later by launching Heute (Skrabal, 2012), which has become Austria's most successful free daily.

\section{Theoretical framework}

The relationship between journalism and - mainly "Western" - democracies has been the subject of much scientific discourse in recent years. Above all, the field of communication studies can look back upon extensive research on the different roles and functions of mass media within a democratic framework. These ground on the assumption that journalism is a mandatory precondition for the functioning of democracy and thereby serves its citizens by enabling democratic processes (Meier, 2007).

The bond of journalism and democracy is a widely shared notion amongst scholars and often includes high expecta- tions. For example, Gurevitch and Blumler (1990) suggested an often-cited list of democratic demands for media performance, commenting that these expectations are "no easy matter to achieve" (p. 26). The listed functions include the "surveillance of sociopolitical environments, reporting of development likely to impinge [...] the welfare of the citizens," "mechanisms for holding officials to account for how they have exercised power," and giving "incentives for citizens to learn, choose, and become involved" (p. 25). This position is also reflected in the long-claimed paradigm in which journalism exists in order to help sustain and animate the public sphere, monitor the government, and provide public value (George, 2013; McQuail, 1992; Moore, 1995; Venturelli, 1998).

Because of the rather idealistic nature of these expectations, it might come as no surprise that the different aspects of the functions described have always faced criticism. For instance, it has been argued that journalism is more entertaining than it is informative by focusing on scandals, violence and political personalities rather than ideologies (Herman \& Chomsky, 1988; Herman \& McChesney, 1997; Keane, 1991; McChesney, 1999), and that the watchdogs get alarmed by the wrong things, leaving voters with very little information about actual political agendas (Bagdikian, 1983; 
Barnett, 2002; Cappella \& Jamieson, 1997; Fallows, 1996; Sabato, 1991).

While journalism's constructive contribution to democracy is more and more challenged, Western journalism is constantly associated with rising economic pressure. The media industry is described as becoming more commercialized than ever before, and the transformation is sometimes discussed in terms of a change from public-driven to market-driven conditions (Croteau \& Hoynes, 2006; LeeWright, Phillips, \& Witschge, 2011; Macnamara, 2010; Wadbring, 2013).

Many scholars have argued that the close linkage between journalism and democracy is endangered, and Western countries are said to be experiencing a decoupling of democracy and journalism (Grönvall, 2015; Josephi, 2013). Josephi (2013) argues that "there has been a time and place when the close linkage of journalism and democracy was valid," but claims that this can no longer be assumed (p. 441). Nerone (2013) even suggests that the way Western journalism is practiced is in itself counterproductive to democratic systems. Free newspapers play a special role in this discussion, as their performance is said to offer lower journalistic quality in most democratically relevant dimensions (for Austria, see Seethaler, 2015), although research shows that working routines are comparable to the paid press (for Denmark, see Sparre, 2017).

Despite scientific doubts concerning the implementation of the public service function within journalistic routine, it has long been codified in European law, thereby legitimizing governmental press subsidies as well as certain violations of European citizens' right to privacy (ECHR, 1985; Article 8 ECHR; Emerson, 1979). Despite recent doubts, EU legislation views traditional mass media as being integral to democracy: the European Convention on Human Rights (ECHR) has long assigned many democracy-producing functions to traditional mass media. They can be found in the Charter of Fundamental Rights of the European Union, which is intertwined with national legislation, as well as in relevant judgments of the ECHR.
Based on this legal framework, Palmstorfer (2015) defines a model that breaks the normative functions of mass media down into an information function, a monitoring function and a communication function. This model stands in line with Moore's (1995) suggestion that mass media bears the role of "informing" and "monitoring." By adding a third function, "communication", Palmstorfer takes the last two decades of evolving digital communication technologies as well as corresponding legislation into account.

Why exactly apply law in general and, more particularly, EU law when studying the press in Austria? Firstly, in contrast to the jumble of journalistic roles and functions discussed in the scientific community, the EU regulatory framework provides the scaffolding for a universal model, which can be tested empirically. This model bridges normative demands reflecting societal responsibilities and abilities of journalism and concise practical implications as expressed in factual jurisdiction.

Secondly, EU legislation and the European Court of Human Rights are seen as a "living instrument" whose "dynamic interpretation" follows societal change processes and therefore "must be interpreted according to present-day conditions" (Letsas, 2013, p. 107). Hence, one of the strengths of the approach of using EU law as a starting point for journalism research is that it allows its scope to be refined according to ongoing societal changes.

Thirdly and finally, there are also various implications of domestic Austrian law for the role of the media in general (Palmstorfer, 2015, pp. 51-54) and of broadcast media in particular (Seethaler \& Beaufort, 2017), as they can serve to deduce empirical hypotheses for journalism's actual societal role in Austria (Riedl, 2018). However, EU law paves the way for international comparative research on that matter: as EU law offers equivalent legal guidelines for all 28 member states, international comparisons might allow country-specific factors that do contribute or endanger democratically relevant functions of the 
media to be identified. Against this backdrop, this study serves as a first step and aims to translate legal implications into empirically measurable constructs using the example of a single country.

\subsection{Information function}

As elections are the core of all representative democracies, citizens need to be supplied with all of the information they need in the polling booth. The mass media bears responsibility for that and should "provide high-quality political information [...] and help citizens to come to well-informed political opinions" (Jandura \& Friedrich, 2014 , p. 352). The freedom of expression and freedom of information are fundamental for that. These pillars are legally based on EU law and specifically codified in Article 10 of the European Convention on Human Rights, stating:

... freedom of expression [...] shall include freedom to hold opinions and to receive and impart information and ideas without interference by public authority and regardless of frontiers $[\ldots]$ in a democratic society. (ECHR, 1953)

However, based on EU court rulings as well as its regulatory framework, the information function does not only imply plain information distribution by the media and journalism. To make sure that citizens in fact receive this relevant information, Palmstorfer (2015) argues that, confronted with both limited resources of attention on the part of citizens as well as with a continuously growing amount of news - often called an "information overload" (Eppler, 2015) - journalists are strongly responsible for analytically selecting this information ("gatekeeping") and presenting it comprehensibly within the scope of journalism.

Thereby, the European Convention on Human Rights as part of the EU legal framework essentially conveys the crux of journalistic responsibilities. Journalism has a responsibility to provide people with relevant information and is therefore a protected enterprise within a democratic society. European citizens have the right to freely make political decisions and partici- pate in democratic elections, and thus depend on journalism's role to enable them to make these political decisions based on relevant information (Schudson, 1998). It is therefore necessary that journalism enacts its gatekeeping mechanism to convey relevant information regarding a plethora of issues to the average citizen. Journalism makes materials relevant to particular issues accessible to its audience, thus, whether directly or indirectly, facilitating and strengthening the democratic process (Palmstorfer, 2015).

\subsection{Monitoring function}

In addition to their duty of conveying selected relevant information in a comprehensive and understandable way to the public, journalists have a monitoring function: according to Palmstorfer (2015), journalists have a responsibility to monitor and criticize government, politics, and the economy in the name of the citizen. While the information function mainly addresses citizens as voters and thus aims to establish democratic representation, the monitoring function aims to maintain this representation during times of governing to ensure the representatives feel obliged to uphold the pledges made before elected. Moreover, this bestowed monitoring responsibility, or public watchdog role, strengthens the democratic process by creating an additional layer of protection against potential detriments or injustices against citizens.

The idea of media's monitoring function basically reflects the legal concept of division of powers that shapes modern constitutional states. Aware of that, legal justification for journalism's monitoring role, as well as emphasis on its importance, is explicitly exemplified in the case of the Norwegian newspaper Bergens Tidende. In this legal precedent, the right to freedom of expression (Article $10 \mathrm{ECHR}$ ) of the newspaper was declared to be violated after a national court condemned it for having disrespected a plastic surgeon's rights by publishing a massive critique of his treatment of patients. The case is insofar significant for the clarification of the media's democratic monitoring func- 
tion as the ECHR stresses that the "public watchdog" role is "vital" to the press (Bergens Tidende and others v. Norway, 2000). An additional 2013 decision adds to the codification of the watchdog role (Węgrzynowski \& Smolczewski v. Poland, 2013).

Finally, as a result of the monitoring function, political decisions are reached under consideration of the public, which the media has integrated. This can both have consequences for the decision-making process as such as well as the decisionmaking behavior of the elected (Palmstorfer, 2015).

\subsection{Communication function}

Besides the expectation of both the informing and monitoring functions, the comparably new communication function as firstly derived from the legal framework by Palmstorfer (2015) demands media to be the "mouthpiece" of the citizens and to interact with them to do so. This has various implications: basically, to identify citizens' needs and necessities and make them public, journalists both need to facilitate active participation by the citizens, motivate them to participate and aim to let these people express their views and perspectives. As the communication should not be unidirectional but the more reciprocal, journalists should focus on dialog and interactivity (Palmstorfer, 2015). This notion of journalism is demonstrated in the ECHR case ruling Castells v. Spain, which hints at the importance of a public discourse:

Freedom of the press affords the public one of the best means of discovering and forming an opinion on the ideas and attitudes of their political leaders [...]. It thus enables everyone to participate in the free political debate which is at the very core of the concept of a democratic society. (Castells v. Spain, 1992)

As clearly demonstrated in this decision, when creating a public forum for the citizenry, media should include everyone even those at the periphery of society. In aiming to do so, media should promote societal diversity and invite both politi- cal and civil society actors to tolerate and accept diverging views of life. The public forum established via the media's communication function may also function as an initial point of social change if it is the collective will of the citizenry as a sovereign entity in democratic societies.

In establishing mutual discourse, the communication function does also face a technical dimension: from a normative perspective, through the advancement of the internet, reciprocal communication can be established and facilitated beyond the limitations associated with traditional media such as newspaper, TV and radio. Thus, it amplifies the possibility of participation, supplementing the democratic process by creating and maintaining various possibilities of interactions, feedback systems, and discourse (e.g., Ferdinand, 2000). ${ }^{2}$

In this context, Palmstorfer (2015) consults Bertolt Brecht's (1979) idea of radio as a means of communication to illustrate this technical dimension. Brecht argues that radio would be the greatest communication technology of public life if it could not only to broadcast, but also receive information. In fact, this development goes beyond online media and influences traditional media equally, pressuring journalists in traditional media to approach this new public service function and find ways to incorporate it within the possibilities of the respective media channel. Hence, the function is undergoing constant change and is therefore rather fluid in its interpretation.

\section{Material and methods}

\subsection{Sample}

A survey was conducted to collect data from Austrian journalists within the Austrian part of the Worlds of Journalism Study ${ }^{3}$, funded by the Austrian Science Fund (FWF). ${ }^{4}$ The survey covered the period between

2 It goes without saying that the internet indeed could not always fulfill these high expectations (e.g., Dahlgren, 2005).

3 http://www.worldsofjournalism.org.

4 Mapping Change in Journalism: How Jour- 
November 2014 and August 2015. The selection of the sample $(N=818)$ was intended to be representative of the population of journalists in Austria. We had initially contacted a total of 2843 journalists with a response rate of 28.77 percent $(n=818)$. 99 percent of these interviewees completed the standardized quantitative survey online, the remaining 1 percent were surveyed via telephone. The journalists were recruited via email, however most of them required a telephone follow-up to ensure completion of the survey.

In order to create a representative sample, a multistage sampling approach was carried out. For that purpose, the population of professional journalists was first estimated: Journalists who are primarily entrusted with journalistic tasks, who select, edit and publish news that has a social function, are guided by professional norms and work primarily in journalism, thus drawing at least 50 percent of their income from journalistic activities, were considered to be professionals. To be able to identify them, the media landscape was analyzed in detail and all editorial departments were identified. Editorial departments were understood as those organizational units that are editorially independent, produce journalistic content and correspond to the functions of journalistic communication. In order to be considered for inclusion in the sample, editorial departments had to have a certain media-specific periodicity, reach and size. Based on these criteria, a list of editorial units was created. This list turned up a total of 4100 professional journalists.

Out of the list of editorial units, a proportionally stratified random sample with two layers, depending on the respective national reach $(0.5 \%-1.5 \%$ vs. $>1.5 \%)$, was chosen. In both layers, every $\mathrm{n}^{\text {th }}$ editorial unit was drawn from media genre-specific lists and classified as a large (= above-average) or small unit. Subsequently, in each of the two layers, 28 journalists were ran-

nalists in Germany, Austria and Switzerland Perceive the Transformation of News Making - Worlds of Journalism (WJS), Part II, funded by the Österreichischer Wissenschaftsfonds FWF, Project Id: I 1341-G16. domly chosen as respondents from large editorial units and 16 journalists from small units. The quotas of the stratified random samples were proportional to the distribution of journalists in the respective media types. The sampling also ensured that journalists in leading positions were represented according to their distribution in the population. The sample size had a confidence level of 95 percent and a margin of error of 3 percent, taking into account the estimated population of Austrian journalists in 2014.

A total of 111 traditional media (daily newspapers, weekly newspapers, news agencies, radio, TV, and magazines) and 22 digital media (stand-alone and spinoff) were identified through that process. A total of 411 participants work in press, of which 336 are employed by paid print media and 75 of which work in free print media. After being contacted, the journalists who agreed to voluntarily participate in the study were informed about the objectives of the research. (For more details on the survey see the Austrian country report available online, Lohmann \& Seethaler, 2016.)

\subsection{Measures and indices}

In order to measure the three described functions, the study addressed professional role perception by asking for the journalists' opinion on journalism's role in society (e.g., Patterson \& Donsbach, 1996): "Please tell me how important each of these things is in your work" (scale from $1=$ unimportant to $5=$ extremely important); for more details on the questionnaire, its contents and structure, see the equivalent international version available online (Worlds of Journalism Study, 2014). Possible answers included several items that specifically respond to all three public service functions described above:

\footnotetext{
Information function (Cronbach's $\alpha=.662$ )

, Be a detached observer

, Report things as they are

, Provide analysis of current affairs

, Provide information people need to make political decisions
} 
Monitoring function (Cronbach's $\alpha=.916$ )

, Monitor and scrutinize political leaders

, Monitor and scrutinize business

\section{Communication function (Cronbach's} $\alpha=.768$ )

, Advocate for social change

, Motivate people to participate in political activity

, Let people express their views

, Promote tolerance and cultural diversity

In order to compensate for economic pressure and thereby take into account recent developments within the field (LeeWright, Phillips, \& Witschge, 2011; Macnamara, 2010), an index for commercialization was also created:

\section{Commercialization (Cronbach's $\alpha=.708$ )}

, Provide entertainment and relaxation

, Provide the kind of news that attracts the largest audience

- Provide advice, orientation and direction for daily life

The internal consistency of each construct, measured with Cronbach's alpha, exhibited adequate reliability in each of the types of influence, following the suggested minimum value of 0.60 in exploratory studies (Robinson, Shaver, \&Wrightsman, 1991).

\subsection{Analysis}

For the analyses, the sample was split into four groups: journalists working in free daily press, journalists working in paid daily press, journalists working in free weekly press and journalists working in paid weekly press. Additionally, the study further analyzed journalists from other media, including TV, radio and online media. The different groups were compared using bivariate difference tests, comparing the mean of the groups (ANOVA).

\section{Results}

Analysis of the responses of Austrian journalists working for daily and weekly newspapers showed that the mean responses of journalists working for paid print media to the information and monitoring functions exceed those of the journalists working for free print media (see Table 1). The mean values for journalists of paid print media are $4.32(N=336, \partial=0.64)$ for the information function and $3.31(N=315, \partial=1.33)$ for the monitoring function. Those working for free print media have mean values of $4.24(N=76, \partial=0.61)$ and $3.03(N=75$, $\partial=1.19$ ), respectively. This demonstrates that paid print media journalists perceive a greater importance of both the information and monitoring functions. However, the differences keep within limits.

On the other hand, mean values for journalists working for free print media exceed the mean values of journalists for paid print media for both the communication function and commercialization index. Journalists working for free print media have mean values of $3.75(N=76, \partial=0.75)$ and $3.94(N=76, \partial=0.72)$ for the communication function and commercialization index, respectively, while journalists working for paid print media have a mean value of $3.44(N=336, \partial=0.88)$ for the communication function and $3.56(N=336, \partial=0.81)$ for the commercialization index. This reflects a perceived emphasis of both the communication function and commercialization index amongst journalists working for free print media.

In summary, by comparing the two groups of journalists it becomes clear that those working for paid newspapers appear to embody the information and monitoring functions more so than journalists working for free media, but the mean values reveal rather minimal differences that are statistically not significant. However, according to ANOVA tests, journalists working for free newspapers are significantly more likely to assume a communication role and are more influenced by commercialization. In general, journalists tend to fulfill the monitoring function least of all, whether a journalist works for a paid or free newspaper.

So far, results have been reported about journalists working in weekly as well as in daily newspapers due to a higher and therefore more scientifically valuable sam- 
Table 1: Democratic functions of journalists working for paid vs. free newspaper in comparison

\begin{tabular}{|c|c|c|c|c|c|}
\hline & & Information & Monitoring & Communication & Commercialization \\
\hline \multirow[t]{3}{*}{ Journalists working for paid newspapers } & M & 4.32 & 3.31 & 3.44 & 3.56 \\
\hline & $N$ & 336 & 315 & 336 & 336 \\
\hline & $S D$ & 0.64 & 1.33 & 0.88 & 0.81 \\
\hline \multirow[t]{3}{*}{ Journalists working for free newspapers } & M & 4.24 & 3.03 & 3.75 & 3.94 \\
\hline & $N$ & 76 & 75 & 76 & 76 \\
\hline & $S D$ & 0.61 & 1.19 & 0.75 & 0.72 \\
\hline \multirow[t]{2}{*}{$\begin{array}{l}\text { Austrian print journalists } \\
\text { (paid vs. free) }\end{array}$} & $\begin{array}{l}d f \text { (within/be- } \\
\text { tween groups) }\end{array}$ & $1 / 410$ & $1 / 388$ & $1 / 410$ & $1 / 410$ \\
\hline & $F$ & 0.923 & 2.806 & $8.312^{* *}$ & $14.724^{* * *}$ \\
\hline
\end{tabular}

Note. Scale ranges from 1-5 (1="role is not influential"; $5=$ "role is extremely influential"). ANOVA results: Journalists working for free/paid print media. Only significant main effects are reported: ${ }^{*} p<.05 ;{ }^{* *} p<.01 ;{ }^{* * *} p<.001$.

Table 2: Democratic functions of journalists working for paid vs. free daily newspaper in comparison

\begin{tabular}{l|c|cccc}
\hline & & Information & Monitoring & Communication & Commercialization \\
\hline Journalists working for paid daily news- & $M$ & 4.37 & 3.38 & 3.46 & 3.57 \\
papers & $N$ & 243 & 228 & 243 & 243 \\
& $S D$ & 0.57 & 1.26 & 0.81 & 0.78 \\
& Variance & 0.32 & 1.59 & 0.65 & 0.61 \\
Journalists working for free daily news- & $M$ & 4.17 & 3.15 & 3.56 & 4.03 \\
papers & $N$ & 13 & 13 & 13 & 13 \\
& $S D$ & 0.45 & 1.18 & 0.65 & 0.75 \\
Austrian daily journalists & Variance & 0.20 & 1.39 & 0.42 & 0.56 \\
(paid vs. free) & df(within/be- & $1 / 254$ & $1 / 239$ & $1 / 254$ & $1 / 254$ \\
& tween groups) & & & & $4.253^{*}$ \\
\hline
\end{tabular}

Note. Scale ranges from 1-5 (1="role is not influential"; $5=$ "role is extremely influential"). ANOVA results: Journalists working for free/paid daily newspapers. Only significant main effects are reported: ${ }^{*} p<.05 ;{ }^{* *} p<.01$.

ple size. If the focus shifts to journalists working in dailies only, we get very similar results. As Table 2 shows, free media journalists score slightly lower on traditional public service functions such as the information and monitoring functions, but higher on the communication function. Contrary to the bigger sample including journalists for daily and weekly newspapers, the differences remain too small to be of statistical significance. Regarding the commercialization index, in which the groups vary significantly in the bigger sample $(p<.001)$, a reduced effect can be demonstrated in the smaller sample as well $(p<.05)$.

These small differences in the two results could be due to the smaller sample size $(N)$. There were only 13 journalists working in the free daily press who par- ticipated in the study compared to the 243 paid press journalists in the sample. However, as the variances for all four indices $(0.20,1.39,0.42$, and 0.56 , respectively) reveal, the free press journalists, albeit fewer in number, are a more homogeneous group, holding similar role perceptions. A certain trend amongst these journalists is therefore to be expected.

To conclude, the findings within the sample of daily journalists appear, to a great extent, to be consistent with journalists working in print in general. Journalists working for paid media appear to embody the monitoring function slightly more than journalists working in free media. However, the differences are not that significant in comparison to journalists working for free press, who are significantly more likely to assume the communication role and 
are more influenced by commercialization. Generally, we can see that journalists, both in paid and free press, tend to fulfill the monitoring function least of all.

\section{Discussion}

Despite the debate amongst scholars and media critics regarding the alleged lack of quality in free dailies, their journalists appear to embody public service functions in a similar way as their colleagues from the paid press. These findings appear to be in line with other studies. In 2007, Bakker concluded that Danish journalists working for free dailies do not have fewer qualifications than those working for paid media, nor are they working with less enthusiasm (Bakker, 2007). Furthermore, Spanish scholars show that neither type of newspaper shows statistical differences with respect to several indicators currently linked to journalistic excellence (Berganza \& De Miguel, 2010). However, the conditions and resources provided by the publisher are different and subsequently limiting. Bakker (2007) stated that publishers invest less in journalism because competition surrounding content is not the main objective. As for the Danish free daily MetroXpress, "only $10 \%$ of the total budget goes to journalists, which is lower than any paid newspaper" (p. 28). With some caution, this can also be assumed to be true of Austrian free dailies.

One of the key findings of this study is the observed connection between the rather new "communication" function and free press journalists: journalists working for free print media are more inclined to advocate for social change, motivate people to participate in political activity, let people express their views and promote tolerance and cultural diversity than their colleagues from the paid press. This was a surprising finding considering that the correlation is present in media that is more influenced by commercialization.

However, a limitation of this study can be found in the fact that the data is based on self-declaration of journalists. Thus, the potential discrepancy of the journalists' attitudes towards their profession and the publishers' notion of journalism could weaken the validity of the statements made in the study. For even if journalists working for the free press are committed to fulfilling public service functions, their working conditions might not fully allow them to do so due to pressure placed on them to increase audience reach with an emphasis on simplification as well as sensationalism. This assumption is supported by the perception that commercialization has a significantly higher influence on journalists working for the free press than on journalists working for paid newspapers. In this context, it might also be possible that journalists working in the free press typically have a different understanding of the respective items: for example, in the eyes of a paid journalist specialized in, say, politics and provided with considerably higher resources, "social change" or "participat[ion] in political activity" might have a drastically stronger democratic notion than it has within interpretative patterns of colleagues from the free press.

Nevertheless, these results are supported by an analysis on the level of media performance: descriptive results of a content analysis by Josef Seethaler (2015) indicate that - in line with the findings of this study - the free press shows a lower level of quality both in terms of objectivity as well as a "discourse index", as they are most strongly reflected in journalists' information function as understood here. In contrast, most of the free newspapers rank higher in a responsiveness index, which is why Seethaler tentatively locates them within the "popular" group of media outlets that can be characterized by a "participatory" orientation. This is also in line with the finding that journalists working for free newspapers are more likely to assume a communication role that contains the goal of "motivating people to participate in political activity."

Furthermore, hints of similar relationships, as reflected in the study, can be found in other countries. According to Lamour (2016), the free daily newspaper L'essentiel in Luxembourg plays a key role 
in displaying the socio-economic rights of cross-border workers and the civic rights of foreigners in the country. A comparable phenomenon is found in Sweden, where, according to Sparre (2016), the MetroXpress operates amongst other aims according to the mission statement "It makes me want to get involved." By publishing selected commentary from social media, fulfilling the communication function is part of the daily routine of the newspaper, although not always in the classic sense of providing a forum for primarily political debate.

In a time when readers are not able to discern automated content from content written by a human, opinionated journalism achieves a new relevance. The notion of information in the very traditional understanding (e.g. "be a detached observer," "report things as they are," as used in the information index) might lose its significance (Clerwall, 2014). This seems especially true as ...

... some aspects of quality, such as being clear and being pleasant to read, received a slightly higher score for human-written content, but others, such as trustworthiness, informative, and objective, were higher for the automated content. (Clerwall, 2014, p. 9)

With this in mind, the predominant emphasis of free newspapers on the communicative function might give them a leading edge, focusing on participatory contents ("advocate for social change," "promote tolerance and cultural diversity"). From this point of view, the free press makes a valuable contribution to society that lies within the notion of a participatory democracy (Curran, 2000).

The first step to rethinking liberal theory is to break free from the assumption that the media are a single institution with a common democratic purpose. Different media should be viewed as having different functions within the democratic system, calling for different kinds of structure and styles of journalism. (Curran, 2000, p. 140)
The paid and free press both seem to fulfill diverging functions, both valuable to democracy in their own way. This assumption is supported by the fact that free papers are surviving in the face of significant opposition from existing daily newspapers, revealing that they are serving a need of readers and advertisers that has not been met by traditional newspapers (Picard, 2001). In almost every European country, paid papers have been losing circulation (Bakker, 2007). However, this has happened even in Norway, where there are no free papers in circulation. Furthermore, as of 2012, the circulation of paid newspapers in Luxembourg appeared to be unaffected by the rise of free dailies (Bakker, 2013). In Austria, paid tabloids are constantly losing to free dailies, but quality newspapers appear hardly affected. The free press seems to coexist with the paid press, as long as it offers a unique "selling" proposition. Even though free papers work with fewer journalists, employ no foreign correspondents, and do not have a significant cultural department, they often offer their own agenda, concentrating on certain topics of interest to a large audience that paid newspapers seem to ignore (Bakker, 2007).

As this study tried to operationalize a normative notion of journalism as defined by the EU and executed by the ECHR, it has tested whether or not this notion applies to journalists' perceptions and their job reality. In this respect it is worth mentioning that the information index is high amongst both paid and free press journalists; both of these values are much higher than the monitoring index values. By EU standards, however, both of these functions are part of the public service standard. Thus, this discrepancy hints that the EU's notion of journalism is not shared by all journalists equally. The next step in our research will therefore be to explore actual functions as defined by journalists in several media sectors and to compare the results with long-lasting normative notions as represented by the legal framework of the EU. Moreover, WJS data allows a total of 67 different participating countries to be analyzed. This broadens the scope from 
a solely "westernized" focus to an open comparative analysis of several regions of the world.

\section{Conclusions}

According to journalists' perception of their function based on the WJS survey, it can be hypothesized that journalists from the free press place slightly less significance on the information and monitoring functions as journalists working for the paid press, albeit the differences are statistically insignificant.

One of the key findings is that journalists working in free press aim to fulfill the communication function significantly more so than journalists working for the paid press. Journalists working for free print media are more inclined to advocate for social change, motivate people to participate in political activity, let people express their views and promote tolerance and cultural diversity. Taking into consideration that the communication function is, above all, fueled by the rise of the internet and influenced by the rise of varying social media networks, the correlation might be exaggerated: the free daily press, as a rather new business model, seems to be more open to newer concepts of journalism. Hints of this correlation can be found in France and Denmark as well (Lamour, 2016; Sparre, 2016).

On another note, free press journalists appear to be significantly more influenced by commercialization than their colleagues working for the paid press. This is likely due to economic pressure as the free press is more dependent on advertisements in order to survive. Free dailies primarily thrive via their openness to more commercialization as a majority of their commercial profits come from advertisements. With the value of advertisements increasing as the audience reach of the newspaper increases, the market orientation may affect the type of subject matter that is reported. This trend tends to simplify and sensationalize the content of free dailies, thus partially restricting the fulfillment of some public service functions (information function and monitoring function). However, following their own agenda, the free press often tends to touch upon topics of interest to the audience that are left out by the paid press, offering participative content (communication function).

Based on this study it can be assumed that free dailies fulfill slightly different functions and satisfy different needs, and might thereby coexist with paid (quality) newspapers. From a democratic standpoint, they both fulfill functions that can be valuable to the public. Finally, it is important to emphasize that the normative notion of journalistic functions, as determined by the aforementioned EU legislation, seems to be only partially represented within journalists' self-perception.

\section{References}

Bagdikian, B.H. (1983). The media monopoly. Boston: Beacon Press.

Bakker, P. (2007). Free daily journalism - anything new? Journalistica, 4, 22-32.

Bakker, P. (2013). The life cycle of a free newspaper business model in newspaper-rich markets. Journalistica, 1, 33-51.

Supporting concentration or promoting diversity? The impact of free dailies on the Austrian newspaper market. In B. Stark \& M. Magin (Eds.), The changing Austrian media landscape (pp. 67-80). Vienna: Verlag der österreichischen Akademie der Wissenschaften. doi:10.1553/relation3s67

Ballarini, L., Alves, A., \& Lamour, C. (2017). Free daily newspapers: Professional norms, business model and routinized production in the metropolis (Introduction). Studies in Communication Sciences, 1, 79-80. doi:10.24434/j.scoms.2017.01.006

Barnett, S. (2002). Will a crisis in journalism provoke a crisis in democracy? The Political Quarterly, 73(4), 400-408. doi:10.1111/1467-923X.00494

Barthold v. Germany, no. 8734/79, 58, ECHR 1985.

Berganza, R., \& De Miguel, R. (2010, October). Free dailies and quality standards: A comparative-exploratory analysis of journalistic excellence among five Spanish daily 
newspapers. Presented at the $3^{\text {rd }}$ European Communication Conference, Hamburg, Germany.

Bergens Tidende and others v. Norway, No. 26132/95, Reports 2000-IV, \$51, decided 2 May 2000.

Brecht, B. (1979). Radio as a Means of Communication: A Talk on the Function of Radio. Screen, 20(3-4), 24-28. doi:10.1093/ screen/20.3-4.24

Cappella, J. N., \& Jamieson, K.H. (1997). Spiral of cynicism: The press and the public good. New York, Oxford: Oxford University Press .

Castells v. Spain, Series A No. 236, \$43, decided 23 April 1992.

Clerwall, C. (2014). Enter the Robot Journalist: Users' perceptions of automated content. Journalism Practice, 8(5), 519-531. doi:10.1 $080 / 17512786.2014 .883116$

Croteau, D., \& Hoynes, W. (2006). The business of media: corporate media and the public interest ( $\left.2^{\text {nd }} \mathrm{ed}\right)$. Thousand Oaks, California: Pine Forge Press.

Curran, J. (2000). Rethinking media and democracy. In J. Curran \& M. Gurevitch (Eds.), Mass media and society (3. ed., pp. 120-154). London: Arnold.

Dahlgren, P. (2005). The Internet, public spheres, and political communication: Dispersion and deliberation. Political Communication, 22(2), 147-162. doi:10.1080/10584600590933160

derstandard.at. (2015, June 10). Neue Eigentumsverhältnisse bei «Heute» [News ownership structure at «Heute»]. Derstandard. at. Retrieved from http://derstandard. at/2000017262693/Heute-hat-neue-Eigentumsverhaeltnisse-mehr-Rot-weniger-Dichand

Emerson, T. I. (1979). The right of privacy and freedom of the press. Harvard Civil RightsCivil Liberties Law Review, 14(2), 329-360.

Eppler, M. J. (2015). Information quality and information overload: The promises and perils of the information age. In L. Cantoni \& J.A. Danowski (Eds.), Communication and technology (pp. 215-232). Berlin; Boston: De Gruyter Mouton.

European Court of Human Rights (adopted 10 December 1948, entered into force 4 September 1950) (ECHR) art 8.
Fallows, J. M. (1996). Breaking the news: how the media undermine American democracy ( $1^{\text {st }}$ ed). New York: Pantheon Books.

Ferdinand, P. (2000). The Internet, democracy and democratization. Democratization, 7(1), 1-17. doi:10.1080/13510340008403642

George, C. (2013). Diversity around a democratic core: The universal and the particular in journalism. Journalism, 14(4), 490-503. doi:10.1177/1464884912464169

Grönvall, J. (2015). De-coupling of journalism and democracy: Empirical insights from discussions with leading Nordic media executives. Journalism, 16(8), 1027-1044. doi:10.1177/1464884914554174

Gurevitch, M., \& Blumler, J. G. (1990). Political communication systems and democratic values. In J. Lichtenberg (Ed.), Democracy and the mass media (pp. 269-289). Cambridge: Cambridge University Press. doi:10.1017/CBO9781139172271.011

Herman, E.S., \& Chomsky, N. (1988). Manufacturing consent: the political economy of the mass media. New York: Pantheon Books.

Herman, E.S., \& McChesney, R.W. (1997). The global media: the new missionaries of corporate capitalism. London \&Washington, DC: Cassell.

Jandura, O., \& Friedrich, K. (2014). The quality of political media coverage. In P. Cobley (Ed.), Political Communication (pp. 351374). Berlin: De Gruyter Mouton.

Josephi, B. (2013). How much democracy does journalism need? Journalism, 14(4), 474489. doi:10.1177/1464884912464172

Keane, J. (1991). The media and democracy. Cambridge, Malden: Polity Press.

Lamour, C. (2016). The Neo-Westphalian public sphere of Luxembourg: The rebordering of a mediated state democracy in a cross-border context. Tijdschrift Voor Economische En Sociale Geografie. doi:10.1111/tesg.12202

Lee-Wright, P., Phillips, A., \&Witschge, T. (2011). Changing journalism. Milton Park, Abingdon, \& New York: Routledge.

Letsas, G. (2013). Letsas, George, The ECHR as a living instrument: Its meaning and its Legitimacy. In A. Føllesdal, B. Peters, \& G. Ulfstein (Eds.), Constituting Europe: the European Court of Human Rights in a national, European, and global context 
(pp. 106-141). New York: Cambridge University Press.

Lohmann, M.-I., \& Seethaler, J. (2016). Worlds of Journalism Study country report. Journalists in Austria. Austrian Academy of Sciences. Retrieved from https://epub. ub.uni-muenchen.de/30966/1/Country_ report_Austria.pdf

Macnamara, J. (2010). Remodelling media: The urgent search for new media business models. Media International Australia, 137(1), 20-35. doi:10.1177/1329878X1013700104

Magin, M., \& Stark, B. (2015). Explaining national differences of tabloidisation between Germany and Austria: Structure, conduct and performance. Journalism Studies, 16(4), 577-595. doi:10.1080/14616 70X.2014.921398

McChesney, R.W. (1999). Rich media, poor democracy: Communication politics in dubious times. Urbana: University of Illinois Press.

McQuail, D. (1992). Media performance: Mass communication and the public interest. London Newbury Park, CA: Sage.

Meier, K. (2007). Journalistik [Journalism Studies]. Konstanz: UVK.

Moore, M.H. (1995). Creating public value, Strategic management in government. Cambridge, MA.: Harvard University Press.

Nerone, J. (2013). The historical roots of the normative model of journalism. Journalism: Theory, Practice \& Criticism, 14(4), 446-458. doi:/10.1177/1464884912464177

Österreichische Auflagenkontrolle (ÖAK) (2016). Auflagenliste Jahresbericht 2015 [Circulations Annual Report 2015]. Retrieved from http://www.oeak.at/wp-content/uploads/2016/06/KORR_J_2015.pdf

Palmstorfer, N. (2015). Die öffentliche Aufgabe der Massenmedien: Demokratiepolitische Aspekte [The public purpose of mass media: Democratic aspects]. In W. Berka, C. Grabenwarter, \& M. Holoubek (Eds.), Qualitätssicherung im Rundfunk und in den Online-Medien. Zehntes Rundfunkforum [Quality Control in Broadcasting and Online Media. $10^{\text {th }}$ Public Broadcasting Forum] (pp. 41-57). Vienna: Manz.

Patterson, T. E., \& Donsbach, W. (1996). News decisions: Journalists as partisan actors.
Political Communication, 13(4), 455-486. doi:10.1080/10584609.1996.9963131

Picard, R. G. (2001). Strategic responses to free distribution daily newspapers. International Journal on Media Management, 3(3), 167-172. doi:10.1080/14241270109389962

Riedl, A. (2018). Which journalists for which democracy? Liberal-representative, deliberative and participatory roles among Austrian journalists. Journalism Studies. doi:10.1080/1461670X.2018.1519638

Robinson, J.P., Shaver, P. R., \& Wrightsman, L. S. (1991). Criteria for ccale selection and evaluation. In J. P. Robinson, P. R. Shaver, L. S. Wrightsman, \& F. M. Andrews (Eds.), Measures of personality and social psychological attitudes (pp. 1-16). San Diego: Academic Press.

Russomanno, J. (2008). Freedom of the Press, Concept of. In W. Donsbach (Ed.), The International Encyclopedia of Communication. Wiley-Blackwell. Retrieved from http://www.communicationencyclopedia.com/subscriber/tocnode. html?id=g9781405131995_yr2012_chunk_ g978140513199511_ss48-1

Sabato, L. (1991). Feeding frenzy: How attack journalism has transformed American politics. New York: The Free Press.

Schudson, M. (1998). The good citizen: A history of American civic life. New York: Martin Kessler.

Seethaler, J. (2015). Qualität des tagesaktuellen Informationsangebots in den österreichischen Medien [Quality of Daily News in Austrian Media]. Vienna: RTR.

Seethaler, J., \& Beaufort, M. (2017). Community media and broadcast journalism in Austria: Legal and funding provisions as indicators for the perception of the media's societal roles. Radio Journal: International Studies in Broadcast \& Audio Media, 15(2), 173-194. doi:10.1386/rjao.15.2.173_1

Serazio, M. (2009). Free newspapers. In C. Sterling (Ed.), Encyclopedia of Journalism (pp. 648-650). Thousand Oaks, CA: Sage. doi:10.4135/9781412972048.n167

Skrabal, F. (2012, May 7). Eva Dichand legt Eigentümer offen: «Heute» und «Krone» in einer Familie [Eva Dichand reveals ownership: «Heute» and «Krone» in one family]. diepresse.at. Retrieved from https://diepresse.com/home/kultur/ 
news/755707/Eva-Dichand-legt-Eigentuemer-offen_Heute-und-Krone-in-einer-Familie

Sparre, K. (2016, March). Journalistic quality in free daily newspapers: A case study of MetroXpress. Paper presented at the conference "T," Metz, France. Presented at the Free Daily Press in Europe 1995-2015, Metz, France.

Sparre, K. (2017). Journalists like the rest of them? A case study of journalistic work routines at a Danish free newspaper. Studies in Communication Sciences, 1, 81-97. doi:10.24434/j.scoms.2017.01.007

Steinmaurer, T. (2008). Austria: Media system. In W. Donsbach (Ed.), The international encyclopedia of communication. Chichester: Wiley-Blackwell. Retrieved from http://www.communicationencyclopedia.com/subscriber/tocnode. html?id=g9781405131995_yr2012_chunk g97814051319956_ss72-1

The Sunday Times v. The United Kingdom, no. 6538/74, 65, ECHR 1979-I.

Trappel, J. (2007). The Austrian media landscape. In G. Terzis (Ed.), European media governance. National and regional dimensions (pp. 63-72). Bristol: intellect.

Venturelli, S. (1998). Liberalizing the European media: Politics, regulation, and the public sphere. Oxford, \& New York: Clarendon.

Wadbring, I. (2013). Levels of commercialisation. In M. Puppis, M. Künzler, \& O. Jarren (Eds.), Medienstrukturen und Medienperformanz [Media structures and media performance] (pp. 119-134). Vienna: Verlag der Österreichischen Akademie der Wissenschaften. doi:10.1553/relation4s119

Węgrzynowski and Smolczewski v. Poland, Appl. No. 33846/07, decided 16 July 2013.

Worlds of Journalism Study. (2014). Master questionnaire, 2012-2014 Version 2.5.1 consolidated. Retrieved from http:// worldsofjournalism.org/fileadmin/Data tables_documentation/Documentation/ WJS_core_questionnaire_2.5.1_consolidated.pdf 
